\section{Response of Young Pecan Trees to Trunk and Foliar Applications of Glyphosate}

\author{
Wheeler G. Foshee III ${ }^{1}$ \\ Department of Horticulture, Auburn University, 101 Funchess Hall, Auburn \\ University, AL 36849
}

\author{
Eugene K. Blythe \\ Department of Plant and Soil Sciences, Mississippi State University, South \\ Mississippi Branch Experiment Station, Poplarville, MS 39470
}

\author{
William D. Goff \\ Department of Horticulture, Auburn University, Auburn University, AL \\ 36849
}

\section{Wilson H. Faircloth \\ USDA/ARS, National Peanut Research Laboratory, Dawson, GA 39842}

\author{
Michael G. Patterson \\ Department of Agronomy and Soils, Auburn University, Auburn University, \\ AL 36849
}

Additional index words. Carya illinoinensis, herbicide exposure, weed control, nut crops

\begin{abstract}
A field experiment was conducted from 1995 to 1999 in central Alabama to determine the effect of repeated applications of glyphosate herbicide on young 'Sumner' pecan trees. Herbicide treatments were applied on 'Sumner' pecan trees varying in age from newly established (first growing season) to established fourth-year growing season trees. Measurements taken included tree mortality, trunk cross-sectional area, nut yield, and nut quality in the third and fourth years of the study. Glyphosate applications were targeted at the lowest 5 to $8 \mathrm{~cm}$ of the tree trunk ("standard" treatment), a percentage (lowest 33\%, 67\%, or 100\%) of the tree trunk below the first scaffold limb, or a percentage (lowest $25 \%, 50 \%, 75 \%$, or $100 \%$ ) of tree foliage to simulate situations ranging from minor spray drift to major misapplication. No adverse effects were detected when glyphosate was applied to trunks, regardless of tree age. However, repeated application of glyphosate to $\mathbf{7 5 \%}$ to $\mathbf{1 0 0 \%}$ of tree foliage resulted in a significant reduction of growth and, in some cases, tree death. Results indicate that limited contact of glyphosate with the lowest 5 to $8 \mathrm{~cm}$ of the trunk of the young pecan tree, which usually occurs during conventional orchard weed management, is unlikely to result in adverse effects on young pecan trees.
\end{abstract}

Weed competition can reduce growth (Patterson et al., 1990; Smith et al., 2002; Wolf and Smith, 1999), yield (Foshee et al., 1997; Patterson and Goff, 1994), and nut quality (Daniell, 1974) of pecan trees. This reduction in growth has been attributed to competition for nutrients (Bould and Jarrett, 1962; Goff et al., 1991; Worley and Carter, 1972) and water (Patterson and Goff, 1994; Ware and Johnson, 1958).

Benefits from improved weed control are well-documented (McEachern and Storey 1984; Norton, 1970; Norton and Storey,

Received for publication 16 May 2007. Accepted for publication 18 Oct. 2007.

We thank Dr. Phil Banks, President, Marathon Agricultural and Environmental Consulting, Inc., Las Cruces, NM, for funding a portion of this research.

${ }^{1}$ To whom reprint requests should be addressed; e-mail foshewg@auburn.edu
1970; Patterson et al., 1990; Patterson and Goff, 1994). Several studies have shown that eliminating all weed competition dramatically increases early growth and yield of young pecan trees (Foshee et al., 1997; Smith et al., 2002, 2005a; Wolf and Smith, 1999). In addition, mulching has been shown to be effective in increasing growth of young pecan trees, although the application of mulch is labor-intensive and costly (Merwin et al., 1994; Smith et al., 2000).

An optimum vegetation-free area has been established by Smith et al. (2005b) to be a circle $1.83 \mathrm{~m}$ in diameter around young pecan trees in bermudagrass [Cynodon dactylon (L.) Pers.] sod. This resulted in maximum tree growth during the first 5 years of growth. Smith et al. (2002) showed similar results in tall fescue [Schedonorus phoenix (Scop.) Holub (syn. Festuca arundinacea Schreb.)] sod with maximum tree growth obtained with a vegetation-free circle 0.91 $\mathrm{m}$ in diameter around newly planted pecans after only 2 years.

Wolf and Smith (1999) reported that growth of young pecan trees was reduced dramatically when one selected dicotyledonous weed species [cutleaf evening primrose (Oenothera laciniata Hill) or Palmer amaranth (Amaranthus palmeri S. Wats.)] was allowed to grow near pecan seedlings, possibly as a result of some allelopathic interaction. In a follow-up study, Smith et al. (2001) documented that growth of container-grown pecans was reduced when trees were irrigated with leachate collected from pots of cutleaf evening primrose.

Typical weed control practices in pecan orchards include preemergent and postemergent herbicide applications (Patterson et al., 1990). Either paraquat $\left[1,1^{\prime}\right.$-dimethyl-4,4' bipyridinium dichloride] or glyphosate [N(phosphonomethyl)glycine] is used for most postemergent applications (Patterson et al., 1990). Paraquat is a restricted-use pesticide and an Environmental Protection Agency (EPA) Class I pesticide as a result of acute toxicity (Miller, 1996a). Glyphosate, on the other hand, is an EPA Class IV pesticide and is very safe for applicators (Miller, 1996b). Smith et al. (2005a) reported that glyphosate controlled all weed species in a study conducted to determine the effects of temporal weed interference in young pecan trees. Glyphosate has excellent postemergent activity against most dicotyledonous and monocotyledonous weed species. Reynolds et al. (2000) and McClelland and Webster (1998) reported excellent glyphosate activity on cutleaf evening primrose, which is typically not controlled with preemergent herbicides recommended for pecan orchards in the southeastern United States (Wolf and Smith, 1999). Consequently, glyphosate is commonly used in many pecan orchards (Patterson, 1997), and inadvertent herbicide contact with trees through spray drift is a recurring hazard and a concern for growers.

This 4-year study was conducted to evaluate the effects of glyphosate applied to the trunks or foliage of young pecan trees as reflected by mortality, trunk cross-sectional area (as a measure of growth), nut yield, and nut quality (nuts with kernels). Application treatments were selected to simulate situations ranging from minor spray drift to major misapplication.

\section{Materials and Methods}

A young [newly planted, first growing season (first GS) and established, fourthgrowing season (fourth GS)] orchard of 'Sumner' pecan trees (grafted onto seedling rootstock) was used in this study initiated in 1995 at the E.V. Smith Research Center in central Alabama. Soil at this location was a complex of Wickham and Cahaba sandy loams (fine-loamy, siliceous, semiactive, thermic Typic Hapludults) with a $\mathrm{pH}$ of 6.0. Trees were planted on a $6.1 \mathrm{~m} \times 6.1-\mathrm{m}$ spacing. All trees were fertilized based on composite leaf and soil samples taken in July 


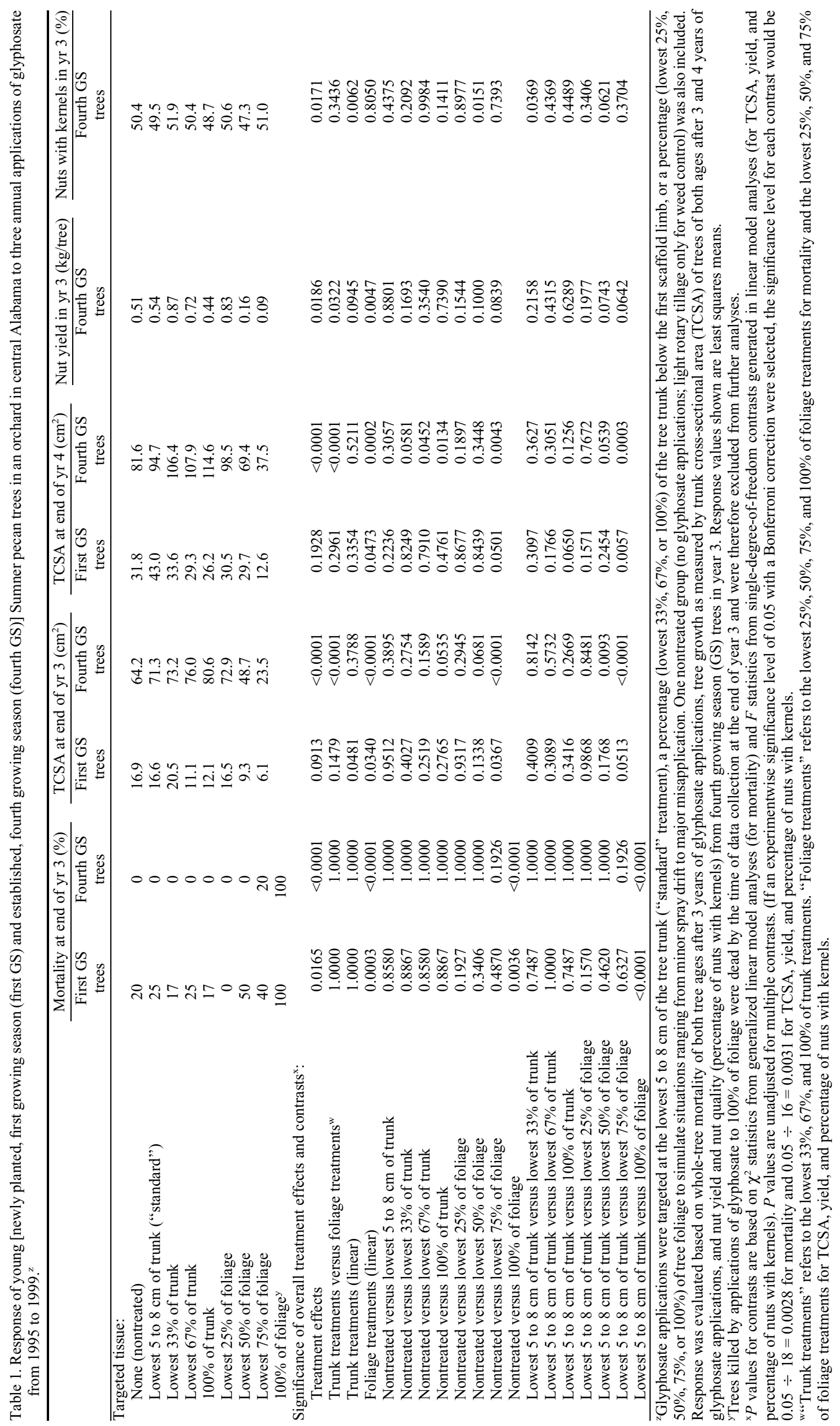


of each year (O'Barr et al., 1989). Standard orchard maintenance practices for disease control and cultural considerations were common to all trees throughout the study (Daniell, 1989; Goff, 1989). Weeds on the orchard floor were controlled with a preemergent application of recommended herbicides (Patterson, 1997). These included a mixture of oryzalin [3,5-dinitro- $\mathrm{N}_{4}, \mathrm{~N}_{4}$-dipropylsulfanilamide] applied at a rate of 3.36 $\mathrm{kg} \cdot \mathrm{ha}^{-1}$ a.i. and diuron $\left[\mathrm{N}^{\prime}-(3,4-\right.$ dichlorophenyl)-N,N-dimethylurea] applied at a rate of $3.36 \mathrm{~kg} \cdot \mathrm{ha}^{-1}$ a.i. In addition, paraquat $(0.56$ $\mathrm{kg} \cdot \mathrm{ha}^{-1}$ a.i.), a postemergent herbicide, was included in the mixture to kill any remaining winter annual weeds present. Herbicides were applied with a three-nozzle, $\mathrm{CO}_{2}$-powered sprayer mounted on an all-terrain vehicle and calibrated to deliver $187 \mathrm{~L} \cdot$ ha. Rotary tillage (without any herbicide applications) every 4 to 6 weeks to a depth of 7.6 to $10.1 \mathrm{~cm}$ with a tractor-mounted, $15-\mathrm{cm}$ wide rotary tiller (model RTS40-01; Bush Hog, Selma, AL) was used to control weeds around trees in one treatment. The orchard was not irrigated. All first GS trees were measured at planting and blocked according to similar size classes to decrease variability. In addition, established fourth GS trees were measured and grouped into blocks according to size.

Treatments were as follows: 1) nontreated (no glyphosate applications; rotary tillage only for weed control); 2) glyphosate applied to the lower 5 to $8 \mathrm{~cm}$ of the trunk (representing the "standard" treatment in orchards where limited glyphosate spray drift occurs during conventional orchard weed management); 3-5) glyphosate applied to the lowest $33 \%$, $67 \%$, and $100 \%$, respectively, of the trunk below the lowest scaffold limb (fourth GS trees) or lowest leaf (first GS trees); and 6-9) glyphosate applied to the lowest $25 \%$, $50 \%, 75 \%$, and $100 \%$, respectively, of the foliage, which was measured and calculated (selected levels were tagged on the trunk of the trees with flagging tape to guide spray applications). Glyphosate treatments were assigned to individual trees using a randomized complete block experimental design with six blocks (replications) for each age of tree. Glyphosate (Roundup Ultra; Monsanto Agricultural Products, St. Louis, MO) was applied at a rate of $1.12 \mathrm{~kg} \cdot \mathrm{ha}^{-1}$ a.i. using a backpack $\mathrm{CO}_{2}$ sprayer calibrated to deliver $140 \mathrm{~L} \cdot \mathrm{ha}^{-1}$ of spray volume. Treatments were applied with a backpack sprayer calibrated to deliver $140 \mathrm{~L} \cdot \mathrm{ha}^{-1}$. Sprayer was equipped with three 8004E T-Jet (Spraying Systems Co., Wheaton, IL) flat fan nozzles spaced evenly on a $1.4-\mathrm{m}$ wide boom. No adjuvants were added to spray solution (included in formulation); the spray water came from a well with a $\mathrm{pH}$ of 6.2. Each tree was sprayed from two sides by an applicator working from the orchard alleys on each side of the tree. Trees were sprayed three times, $60 \mathrm{~d}$ apart, starting 15 Apr. of each year during this 4-year study. Tree mortality was determined for trees of both ages at the end of the third year of application. Trunk cross-sectional area (TCSA) was determined using a measure of trunk circumference at a marked point $15 \mathrm{~cm}$ aboveground level as a measure of growth for trees of both ages at the end of years 3 and 4 . Pecan nut yield (weight of nuts harvested from each tree) and nut quality (percentage of nuts with kernels) were determined for fourth GS trees at the end of year 3 only as a result of a crop failure in year 4, which was attributed to the off-crop year that is often seen in pecans (Goff, 1989).

Data were analyzed for each age of tree separately using a generalized linear model (binomial distribution and probit link function) with the GENMOD procedure of SAS (version 9.1; SAS Institute, Cary, NC) for mortality and a general linear model with the GLM procedure of SAS for TCSA, nut yield, and percentage of nuts with kernels.

\section{Results and Discussion}

Newly planted (first growing season) trees. At the end of year 3, application of glyphosate to $100 \%$ of the foliage resulted in greater tree mortality compared with nontreated trees and trees receiving the "standard" treatment (glyphosate applied to the lowest 5 to $8 \mathrm{~cm}$ of the trunk) (Table 1). Mortality of trees receiving other glyphosate treatments was similar to untreated trees and trees receiving the "standard" treatment. Tree mortality increased linearly as the amount of foliage receiving application of glyphosate increased from $25 \%$ to $100 \%$ (Table 1). Because all trees died in response to application of glyphosate to $100 \%$ of the foliage, these trees were excluded from further analysis. Data provided no strong evidence ( $P$ values near or below 0.01$)$ of any adverse effect of glyphosate treatments on TCSA in comparison with nontreated trees at the end of year 3 .

At the end of year 4, treatments involving application of glyphosate (12 total applications) to tree trunks had not negatively impacted tree survival or TCSA (Table 1). Data indicated that repeated application of glyphosate to $75 \%$ to $100 \%$ of the foliage was needed to negatively impact survival or TCSA of these first GS trees. This demonstrates that an occasional "drift application" of glyphosate to the lower trunk of first GS pecan trees in a production orchard is unlikely to have an adverse affect on tree survival or growth.

Foliage sprayed with glyphosate dropped from the trees within 4 to 6 weeks. When trees receiving glyphosate applications to the foliage were not killed, new growth developed abnormally (Fig. 1).

Established (fourth growing season) trees. Effects of treatments on tree mortality of established trees at the end of year 3 were consistent with effects on newly planted, first GS trees. Application of glyphosate to $100 \%$ of the foliage resulted in $100 \%$ mortality (Table 1); therefore, these trees were excluded from further analysis.

At the end of year 3, trees exhibited an increase in mortality and decrease in TCSA

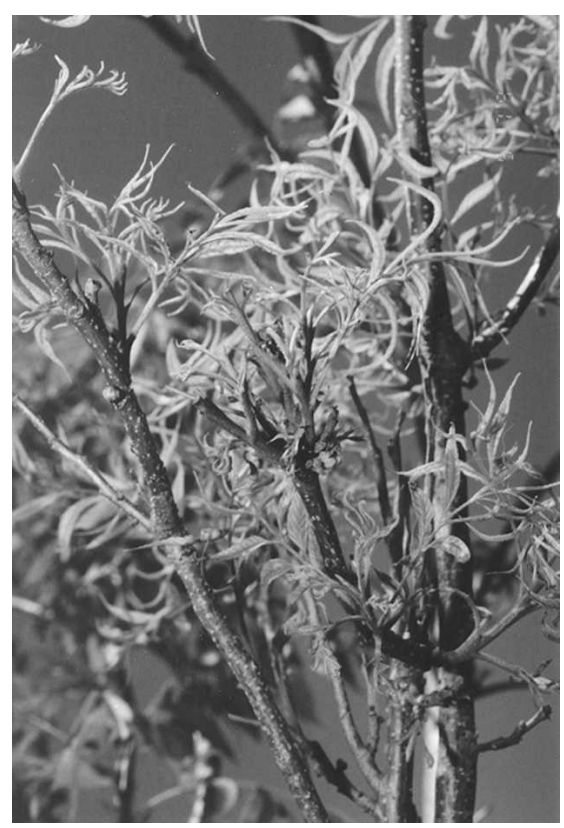

Fig. 1. Abnormal development of new growth on young 'Sumner' pecan trees (newly planted, first growing season trees at the initiation of the study) after 12 repeated foliar applications of glyphosate (i.e., major misapplication) over 4 years (three applications every $60 \mathrm{~d}$ during each growing season) with glyphosate applied at a rate of $1.12 \mathrm{~kg} \cdot \mathrm{ha}^{-1}$ a.i.

as the percentage of the foliage receiving applications of glyphosate increased from $25 \%$ to $100 \%$ (Table 1 ). Comparison between the trunk and foliage treatments indicated a highly significant difference in TCSA with the trunk treatments group having greater TCSA than the foliage treatments group (Table 1). Nontreated trees exhibited greater TCSA than trees receiving application of glyphosate to the lowest $75 \%$ of the foliage (Table 1). In addition, trees receiving the "standard" treatment had greater TCSA than trees that received glyphosate to the lowest $50 \%$ and $75 \%$ of the foliage (Table 1 ).

At the end of year 4, some differences in growth among treatments were again evident. Trees receiving application of glyphosate to their trunks had greater TCSAs $(\approx 60 \%$ greater) than the foliar-treated trees (Table 1). A decreasing linear response in TCSA with increasing percentage of the foliage receiving glyphosate applications continued to be evident (Table 1). Nontreated trees and trees receiving the "standard" treatment exhibited greater TCSAs than trees receiving glyphosate applications to the lowest $75 \%$ of the foliage. Like with first GS trees, foliage receiving applications of glyphosate dropped from the trees within 4 to 6 weeks, whereas any new growth on these trees developed abnormally (Fig. 2).

There was a marginal indication $(P$ values $\approx 0.10$ ) that yield of nuts in year 3 was affected by foliar applications of glyphosate in comparison with results from nontreated trees with yield declining as percentage of the foliage receiving applications of glyphosate increased 


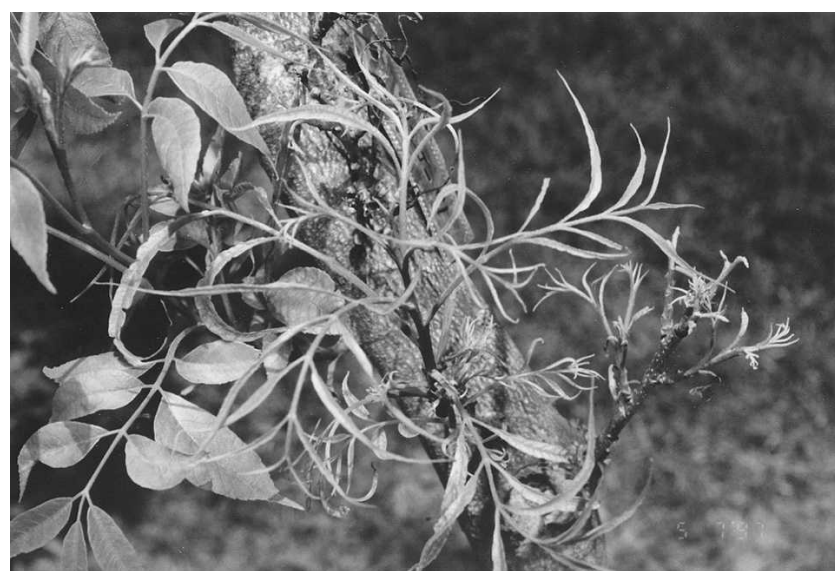

Fig. 2. Abnormal development of new growth on young 'Sumner' pecan trees (established, fourth growing season trees at the initiation of the study) after 12 repeated foliar applications of glyphosate (i.e., major misapplication) over 4 years (three applications every $60 \mathrm{~d}$ during each growing season) with glyphosate applied at a rate of $1.12 \mathrm{~kg} \cdot \mathrm{ha}^{-1}$ a.i.

(Table 1). There was no evidence of any effect on nut quality after 3 years of application. Some indication of a decreasing linear trend in nut quality in year 3 with increasing percentage of the trunk receiving applications of glyphosate (Table 1) was not well substantiated by comparison of trees receiving trunk treatments with nontreated trees or with trees receiving the "standard" treatment.

Results from this 4-year study revealed that application of glyphosate to the trunk of established, fourth GS pecan trees did not significantly affect mortality, growth, yield, or nut quality. However, repeated application of glyphosate to foliage can have an adverse effect. However, occasional drift of glyphosate to the lower trunk of young, established pecan trees is unlikely to cause any adverse effect.

A comparison between nontreated trees and trees receiving applications of glyphosate to the trunk gave some marginal indication that rotary tillage may have negatively affected growth of fourth GS trees, possibly by the disk itself damaging feeder roots, but this was not clearly established. Tillage in pecan orchards is not recommended as a result of reduction in yields from moisture loss (Patterson and Goff, 1994) and damage to feeder roots (Goff, 1989).

Effects of glyphosate contact with young pecan trees have not been previously reported. The use of glyphosate in pecan orchards would be beneficial to pecan growers, particularly to clean up troublesome weeds like cutleaf evening primrose, which at very low number has been shown by Wolf and Smith (1999) to dramatically reduce growth of young pecan trees. Results of this study indicate that occasional contact of young pecan trees with glyphosate is unlikely to significantly affect tree growth or survival.

\section{Literature Cited}

Bould, C. and R.M. Jarrett. 1962. The effect of cover crops and NPK fertilizers on growth, crop yield and leaf nutrient status of young dessert apple trees. J. Hort. Sci. 37:58-82. control on yield and quality of pecans. Proc. S.E. Pecan Growers Assn. 67:35-38.

Daniell, J.W. 1989. Irrigation, p. 73-86. In: W.D Goff, J.R. McVay, and W.S. Gazaway (eds.). Pecan production in the southeast: A guide for growers. Ala. Coop. Ext. Serv., Auburn Univ., AL.

Foshee, W.G. III, R.W. Goodman, M.G. Patterson, W.D. Goff, and W.A. Dozier, Jr. 1997. Weed control increases yield and economic returns from young 'Desirable' pecan trees. J. Amer. Soc. Hort. Sci. 122:588-593.

Goff, W.D. 1989. Pecan production. Ala. Coop. Ext. Serv. Circ. ANR-54, Auburn Univ., AL.

Goff, W.D., M.G. Patterson, and M.S. West. 1991. Orchard floor management practices influence elemental concentrations in young pecan trees. HortScience 26:1379-1381.

McClelland, M.R. and E. Webster. 1998. Summary of preplant weed control options for conservation tillage. Special Report-Ark. Agr. Exp. St. Univ. of Ark. p. 137-139.

McEachern, G.R. and J.B. Storey. 1984. Low control of pecan weeds. Pecan Quarterly 18 : 27-30.

Merwin, I.A., W.C. Stiles, and H.M. van Es. 1994 Orchard groundcover management impacts
Daniell, J.W. 1974. The effects of chemical weed volume, high concentrate. Roundup herbicide on soil physical properties. J. Amer. Soc. Hort. Sci. 119:216-222.

Miller, T.L. 1996a. Pesticide information profiles: Paraquat. Oregon St. Univ. 4 May 2007. <http:// extoxnet.orst.edu/pips/paraquat.htm $>$.

Miller, T.L. 1996b. Pesticide information profiles: Glyphosate. Oregon St. Univ. Accessed 4 May 2007. <http://extoxnet.orst.edu/pips/glyphosa. htm>.

Norton, J.A. 1970. Chemical weed control in bearing and nonbearing pecan [Carya illinoinensis (Wang.) K. Koch] orchards. Diss. Abstr. 31:2402.

Norton, J.A. and J.B. Storey. 1970. Effect of herbicides on weed control and growth of pecan trees. Weed Sci. 18:522-524.

O'Barr, R.D., M. Smith, G. Taylor, and W.D. Goff. 1989. Pecan nutrition, p. 61-72. In: W.D. Goff, J.R. McVay, and W.S. Gazaway (eds.). Pecan production in the southeast: A guide for growers. Ala. Coop. Ext. Serv., Auburn Univ., AL.

Patterson, M.G. 1997. Pecan weed control, p. 332 336. In: W.S. Gazaway (ed.). Alabama Pest Mgt. Handbook. Vol. 1. Ala. Coop. Ext. Sys., Auburn Univ., AL.

Patterson, M.G. and W.D. Goff. 1994. Effects of weed control and irrigation on pecan (Carya illinoinensis) growth and yield. Weed Technol. 8:717-719.

Patterson, M.G., G. Wehtje, and W.D. Goff. 1990. Effects of weed control practices and irrigation on the growth of young pecans. Weed Technol. 4:892-984.

Reynolds, D., S. Crawford, and D. Jordan. 2000. Cutleaf evening primrose control with preplant burndown herbicide combinations in cotton. J. Cotton Sci. 4:124-129.

Smith, M.W., B.L. Carroll, and B.S. Cheary. 2000. Mulch improves pecan tree growth during orchard establishment. HortScience 35:192195.

Smith, M.W., B.S. Cheary, and B.L. Carroll. 2002. Fescue sod suppresses young pecan tree growth. HortScience 37:1045-1048.

Smith, M.W., B.S. Cheary, and B.L. Carroll. 2005a. Temporal weed interference with young pecan trees. HortScience 40:1723-1725.

Smith, M.W., B.S. Cheary, and B.L. Carroll. 2005b. Size of vegetation free area affects nonbearing pecan tree growth. HortScience 40:1298-1299.

Smith, M.W., M.E. Wolf, B.S. Cheary, and B.L. Carroll. 2001. Allelopathy of bermudagrass, tall fescue, redroot pigweed, and cutleaf evening primrose on pecan. HortScience 36:10471048.

Ware, L.M. and W.A. Johnson. 1958. Certain relationships between fertilizer and cultural practices, nitrate and moisture content of the soil, and responses of pecan trees. Proc. S.E. Pecan Growers Assn. 51:10-17.

Wolf, M.E. and M.W. Smith. 1999. Cutleaf evening primrose and Palmer amaranth reduce growth of nonbearing pecan trees. HortScience 34:1082-1084.

Worley, R.E. and R.L. Carter. 1972. Effect of four management systems on parameters associated with growth and yield of pecan. J. Amer. Soc. Hort. Sci. 98:541-546. 